\title{
Wheat Straw-Derived Biochar Enhanced Nitrification in a Calcareous Clay Soil
}

\author{
Chaoxu Wang, ${ }^{1 *}$, Shaorong Chen ${ }^{1,2}$, Lijun Wu ${ }^{1}$, \\ Feng Zhang ${ }^{1,2}$, Jianguo Cui ${ }^{1,2}$ \\ ${ }^{1}$ College of Environmental Science and Engineering, Taiyuan University of Technology, \\ Jinzhong 030600, China \\ ${ }^{2}$ Innovation Center for Postgraduate Education in Municipal Engineering of Shanxi Province, \\ Jinzhong 030600, China
}

Received: 22 April 2017

Accepted: 19 August 2017

\begin{abstract}
Biochar's production and application in soils has been suggested as a means of abating climate change by sequestering carbon while simultaneously providing energy and increasing crop yields. However, little is known about biochar's effect on nitrification in alkaline soil. This study focused on the effect of wheat straw-derived biochar $(0 \%, 2 \%, 5 \%$, and $10 \%, \mathrm{w} / \mathrm{w})$ on nitrification in a calcareous clay soil with an incubation experiment. Moreover, the variations of ammonia-oxidizing bacteria (AOB) amount, urease activity, $\mathrm{pH}$, and inorganic nitrogen contents during the incubation and their relationships with potential nitrification rates were also explored. The results indicated that nitrification was enhanced by wheat straw-derived biochar and showed an obvious dose-response to biochar application rate. Generally, the potential nitrification rate increased with incubation time elapsing for all four treatments, which were in the ranges of 21.0-33.9, 23.7-45.1, 21.4-57.5, and 31.8-66.1 nmol N/(g dry soil-h), respectively. The potential nitrification rate increased by 1.36-2.40 times at $10 \%$ biochar application rate compared with the control $(0 \%)$ at the same incubation stage. Except for $\mathrm{NH}_{4}^{+}-\mathrm{N}$ content of the soil-biochar mixture, AOB amount, urease activity, $\mathrm{pH}$, and $\mathrm{NO}_{3}^{-}-\mathrm{N}$ content all showed increasing trends during incubation. Moreover, correlation analysis indicated that the potential nitrification rate was positively correlated with AOB amount, urease activity, $\mathrm{pH}$, and $\mathrm{NO}_{3}^{-}-\mathrm{N}$ content $(\mathrm{r} \geq 0.713, \mathrm{P}<0.01)$, but negatively correlated with $\mathrm{NH}_{4}^{+}-\mathrm{N}$ content $(\mathrm{r}=-0.408, \mathrm{P}<0.01)$. Notably, though the biochar application in the Loess Plateau region has more benefits for soil condition improvement, the enhanced nitrification induced by biochar may pose a negative effect on fertilizer bioavailable efficiency in the agricultural system.
\end{abstract}

Keywords: biochar, nitrification, calcareous clay soil, ammonia-oxidizing bacteria, urease activity

*e-mail: cxwang127@126.com 


\section{Introduction}

Overuse of chemical fertilizer in agriculture has caused serious nitrogen $(\mathrm{N})$ loss and water pollution problems in China, causing surface water eutrophication by runoff, and groundwater inorganic- $\mathrm{N}$ pollution by leaching [1-2]. The Loess Plateau is located in an arid and semi-arid area, which was the most serious soil-erosion area in the world, and the shortage of water resources and lower soil fertility were the main factors affecting agricultural yield in this region [3].

Recently, literature has shown that biochar has the potential to affect the physical and chemical properties of soils, including soil structures and water conditions [4-5]. Moreover, previous studies have indicated that wood- or manure-based biochars can reduce leaching of fertilizer $\mathrm{N}$ in highly weathered subtropical or tropical soils using pot experiments [6], repacked soil columns [7-9], or suction cup lysimeters in fields [10-11]. Therefore, biochar's incorporation into the loess soil may not only improve the water-holding capacity of soil but also could retard nitrogen leaching.

Though biochar has the potential to hold water and reduce inorganic-N leaching, the effect of biochar on nitrification in soil (as one of the main ways of soil nitrogen transformations) and the related mechanisms remain poorly understood. Several studies have shown that biochar may promote nitrification in acidic soils. For example, DeLuca et al. showed that biochar amendments significantly enhance nitrification in acidic $(\mathrm{pH}$ 4.226.81) pine-forest soils [12]. Van Zwieten et al. reported the increased nitrification following biochar amendment in acidic sandy soil ( $\mathrm{pH} 4.5)$ under long-term intensive vegetable production using a pot experiment [13]. Consistent with previous studies, Nelissen et al. also indicated that net nitrification was significantly stimulated (0.91 to $0.54 \mu \mathrm{g} \mathrm{N} /(\mathrm{g} \cdot d a y)$ ) by a maize-biochar (produced at $550^{\circ} \mathrm{C}$ ) addition in an acidic loamy sand soil ( $\mathrm{pH}$ 4.98) [14]. The reasons for this phenomenon may be that biochar alters the activity of the nitrifying community and removes inhibiting phenols in soils as the authors suggested.

However, how about biochar's effect on nitrification in alkaline soil? Up to now it has been highly likely that there is no evident stimulating effect of biochar on nitrification in calcareous arable soils. Therefore, the study on biochar's effect on nitrification in calcareous clay soil is necessary. Further, determining nitrificationrelated variables' (such as ammonia-oxidizing bacteria (AOB) amount, urease activity, $\mathrm{pH}$, and inorganic-N contents) responses to biochar incorporation into soil and their relationships with nitrification may be helpful for understanding biochar's effect on nitrification comprehensively.

Therefore, the specific objectives of this study were to:

1) Explore the effect of wheat straw-derived biochar on potential nitrification rate of the calcareous clay soil collected from a Loess Plateau cropland.
2) Determine biochar's effects on $\mathrm{AOB}$ amount, urease activity, $\mathrm{pH}$, and inorganic- $\mathrm{N}$ contents and their relationships with potential nitrification rate.

3) Understand the underlying mechanisms of biochar's effect on nitrification.

\section{Materials and Methods}

Soil and Biochar

Soil

The soil was collected from the surface layer $(0-20 \mathrm{~cm})$ of a cropland in the suburb of Jinzhong, Shanxi Province, China, along the southeastern margin of the Loess Plateau. The soil was air-dried for one month and passed through a $2-\mathrm{mm}$ sieve to remove roots and plants, then mixed for storage. The soil had a $\mathrm{pH}$ of $8.11 \pm 0.01$ (w:v, 1:5) and an organic matter of $37.6 \pm 1.97 \mathrm{~g} / \mathrm{kg}$. The $\mathrm{NH}_{4}^{+}-\mathrm{N}, \mathrm{NO}_{3}^{-}{ }^{-} \mathrm{N}$ and $\mathrm{NO}_{2}{ }^{-} \mathrm{N}$ contents of the soil are $36.2 \pm 6.56,14.1 \pm 0.80$, and $0.16 \pm 0.02 \mathrm{mg} / \mathrm{kg}$, respectively. The soil texture corresponds to clay in the USDA textural soil classification.

\section{Biochar}

The biochar used in the experiment was produced from wheat straw by the Sanli New Energy Company, Henan, China. The biochar was produced by pyrolysis of the wheat straw at $350-550^{\circ} \mathrm{C}$. For the study, the biochar was ground to pass through a $2-\mathrm{mm}$ sieve, and mixed thoroughly to obtain a powder that would mix more uniformly with the soil. The wheat straw-derived biochar had a $\mathrm{pH}$ of $10.4\left(\mathrm{H}_{2} \mathrm{O}\right)$, a bulk density of $0.65 \mathrm{~g} / \mathrm{cm}^{3}$, and a specific surface area of $8.92 \mathrm{~m}^{2} / \mathrm{g}$. Organic carbon, total nitrogen, and total ash contents of the biochar were $46.7 \%, 0.59 \%$, and $20.8 \%$, respectively [15-16].

\section{Incubation Experiment}

An incubation experiment was conducted in a series of $250-\mathrm{mL}$ plastic bottles in order to better understand the effects of wheat straw-derived biochar on potential nitrification rate, and its relationship with ammoniaoxidizing bacteria (AOB) amount, urease activity, $\mathrm{pH}$, and inorganic nitrogen contents of the biochar-amended calcareous clay soil. The bottles contained $200 \mathrm{~g}$ (ovendry basis) homogeneous, 2-mm-sieved, and air-dried soil samples mixed with $4.0,10$, and $20 \mathrm{~g}$ wheat strawderived biochar for $2 \%, 5 \%$, and $10 \%$ application rate, respectively. And there was also a control treatment without biochar. Altogether, the experiment consisted of four treatments with three replicates $(n=12)$. Deionized water was added to all of the bottles in order to bring the soil moisture content up to $70 \%$ water-holding capacity. The bottles were covered with polyethylene film punctured with needle holes to maintain an aerobic condition, and were incubated at room temperature $\left(25^{\circ} \mathrm{C}\right)$ in the dark. 
We compensated for water loss due to evaporation by adding the appropriate amount of deionized water every day. Three replicate soil samples were collected from three individual bottles at $0,3,7,10,14,21,28,35,42$, 49 , and 56 days, and the potential nitrification rate, AOB amount, urease activity, $\mathrm{pH}$, and inorganic-N contents of each soil sample were determined within $24 \mathrm{~h}$.

\section{Potential Nitrification Rate Determination}

The potential nitrification rate of the soil sample collected from the test bottle was measured using a chlorate inhibition method with some modifications according to Kurola et al. [17]. Briefly, $5.0 \mathrm{~g}$ of fresh sample (transformed to dry weight during calculation) was added to a $50-\mathrm{mL}$ centrifuge tube containing $20 \mathrm{~mL}$ phosphate buffer solution (PBS) (g/L: NaCl, 8.0; KCl, 0.2; $\mathrm{Na}_{2} \mathrm{HPO}_{4}$, $\left.0.2 ; \mathrm{NaH}_{2} \mathrm{PO}_{4}, 0.2 ; \mathrm{pH}, 7.4\right)$ with modified ammonium concentration $\left(1 \mathrm{mmol} / \mathrm{L}\left(\mathrm{NH}_{4}\right)_{2} \mathrm{SO}_{4}\right)$. Potassium chlorate with a final concentration of $10 \mathrm{mmol} / \mathrm{L}$ was added to inhibit nitrite oxidation. The suspension was incubated $(170 \mathrm{rpm})$ in the dark at $25^{\circ} \mathrm{C}$ for $6.5 \mathrm{~h}$ so as to avoid the impact of ammonium depletion on potential nitrification rate. The time zero sample was collected $0.5 \mathrm{~h}$ after incubation. Subsequently, at the time points 1.5, 2.5, 4.5, and $6.5 \mathrm{~h}$ after incubation the suspensions were collected from the individual time-series centrifuge tubes. The produced nitrite was extracted from the collected samples with $5 \mathrm{~mL}$ of $2 \mathrm{~mol} / \mathrm{L} \mathrm{KCl}$ and determined by a spectrophotometer at a wavelength of $540 \mathrm{~nm}$ with $\mathrm{N}$-(1-naphthyl) ethylenediamine dihydrochloride. The potential nitrification rate was calculated from the linear increase of $\mathrm{NO}_{2}^{-}-\mathrm{N}$ concentration in the suspension during the $6.5 \mathrm{~h}$.

\section{Determining Ammonia-Oxidizing Bacteria Amount}

The dilution-plate method was used to quantify the amount of AOB in the soil-biochar mixture [18]. The culture medium was specialized for $\mathrm{AOB}\left(\mathrm{CaCO}_{3}\right.$, $5.0 \mathrm{~g} ;\left(\mathrm{NH}_{4}\right)_{2} \mathrm{SO}_{4}, 2.0 \mathrm{~g} ; \mathrm{K}_{2} \mathrm{HPO}_{4}, 0.75 \mathrm{~g} ; \mathrm{NaH}_{2} \mathrm{PO}_{4}$, $0.25 \mathrm{~g} ; \mathrm{MgSO}_{4} \cdot 7 \mathrm{H}_{2} \mathrm{O}, 0.03 \mathrm{~g} ; \mathrm{MnSO}_{4} \cdot 4 \mathrm{H}_{2} \mathrm{O}, 0.01 \mathrm{~g} ; \mathrm{NaCl}$, $2.0 \mathrm{~g} ; \mathrm{H}_{2} \mathrm{O}, 1000 \mathrm{~mL}$; pH, 7.1; agar, $\left.1.7 \%(\mathrm{~g}: \mathrm{mL})\right)$. The culture medium, distilled water, and all kinds of vessels were autoclaved at $121^{\circ} \mathrm{C}$ for $30 \mathrm{~min}$.

$3.0 \mathrm{~g}$ fresh soil was added into $30 \mathrm{~mL}$ sterile water in a $150 \mathrm{~mL}$ triangle bottle and vibrated for $10 \mathrm{~min}$ to form a homogeneous soil suspension. Then $1 \mathrm{~mL}$ soil suspension was added into $9 \mathrm{~mL}$ sterile water (designated as $10^{-1}$ ), and successively diluted into the next gradient following the same pattern (designated as $10^{-2}$ ) in a sterile operating platform. After that, both of the two inoculums $(0.05 \mathrm{~mL})$ were spread onto the surface of the prepared culturemedium plate evenly with a coating rod separately with three replicates. And then all the inoculated plates were put into an incubator at a constant temperature of $30^{\circ} \mathrm{C}$ for three days, and the colonies formed on the plate were counted artificially.

The AOB amount of soil sample was calculated as follows:

$$
\begin{gathered}
\mathrm{N}=\Sigma \mathrm{C} /\left[\left(\mathrm{n}_{1}+0.1 \mathrm{n}_{2}\right) \mathrm{d}\right] \\
\mathrm{AOB}_{\text {amount }}=600 \mathrm{~N} / \mathrm{m}
\end{gathered}
$$

...where:

$\mathrm{N}$ : the AOB amount in the $0.05 \mathrm{~mL}$ soil suspension

$\Sigma \mathrm{C}$ : the total amount of colonies on the $10^{-1}$ and $10^{-2}$ dilution plates

$\mathrm{n}_{1}: 3$, the amount of plate spread with $10^{-1}$ dilution

$\mathrm{n}_{2}: 3$, the amount of plate spread with $10^{-2}$ dilution

$\mathrm{d}: 10^{-1}$, the dilution gradient

600: multiple between $30 \mathrm{~mL}$ and $0.05 \mathrm{~mL}$

$\mathrm{m}$ : dry weight of the soil used for soil suspension making $(\mathrm{g})$

$\mathrm{AOB}_{\text {amount }}$ : the AOB amount (individual/g dry soil)

$$
\begin{gathered}
\text { Determining Urease Activity, } \mathrm{pH}, \\
\text { and Inorganic Nitrogen Content } \\
\text { of the Soil-Biochar Mixture }
\end{gathered}
$$

Soil urease activity was determined by indophenol colorimetric method and expressed as $\mu \mathrm{g} \mathrm{NH}_{4}{ }^{+}-\mathrm{N} /(\mathrm{g}$ dry soil $\cdot h)\left(37^{\circ} \mathrm{C}\right)[19]$. Soil $\mathrm{pH}$ was measured by acidometer (Mettler-Toledo, FE20K). Soil inorganic nitrogen was determined as follows: $5.0 \mathrm{~g}$ soil sample was suspended with $50 \mathrm{~mL} \mathrm{KCl}(2 \mathrm{~mol} / \mathrm{L})$ and vibrated for $1 \mathrm{~h}$ in the dark at $25^{\circ} \mathrm{C}$ and $170 \mathrm{rpm}$, then $10 \mathrm{~mL}$ supernatant was filtered through a $0.45 \mu \mathrm{m}$ membrane and the concentrations of $\mathrm{NH}_{4}^{+}-\mathrm{N}$ and $\mathrm{NO}_{3}^{-}-\mathrm{N}$ were determined by colorimetry [20].

\section{Data Analyses}

The variance between any triplicate measurement in this study was smaller than 5\%. Variance analysis (one-way ANOVA) was examined by the protected LSD multiple range test $(P<0.05)$ using Statistica 6.0 software. The graphing was performed using OriginPro 8.0 software, and the correlation analysis was carried out by SPSS 18.0 .

\section{Results and Discussion}

\section{Biochar's Effect on Potential Nitrification Rate}

In the incubation experiment, the wheat straw-derived biochar showed significant $(P<0.001)$ effect on potential nitrification rate of the calcareous clay soil at any incubation stage (Table S1, Supplemental Information (SI)). As a whole, the potential nitrification rate was enhanced by biochar amendment obviously in the soil, and showed positive dose-response to the biochar application rate. At the same incubation stage, the potential nitrification 

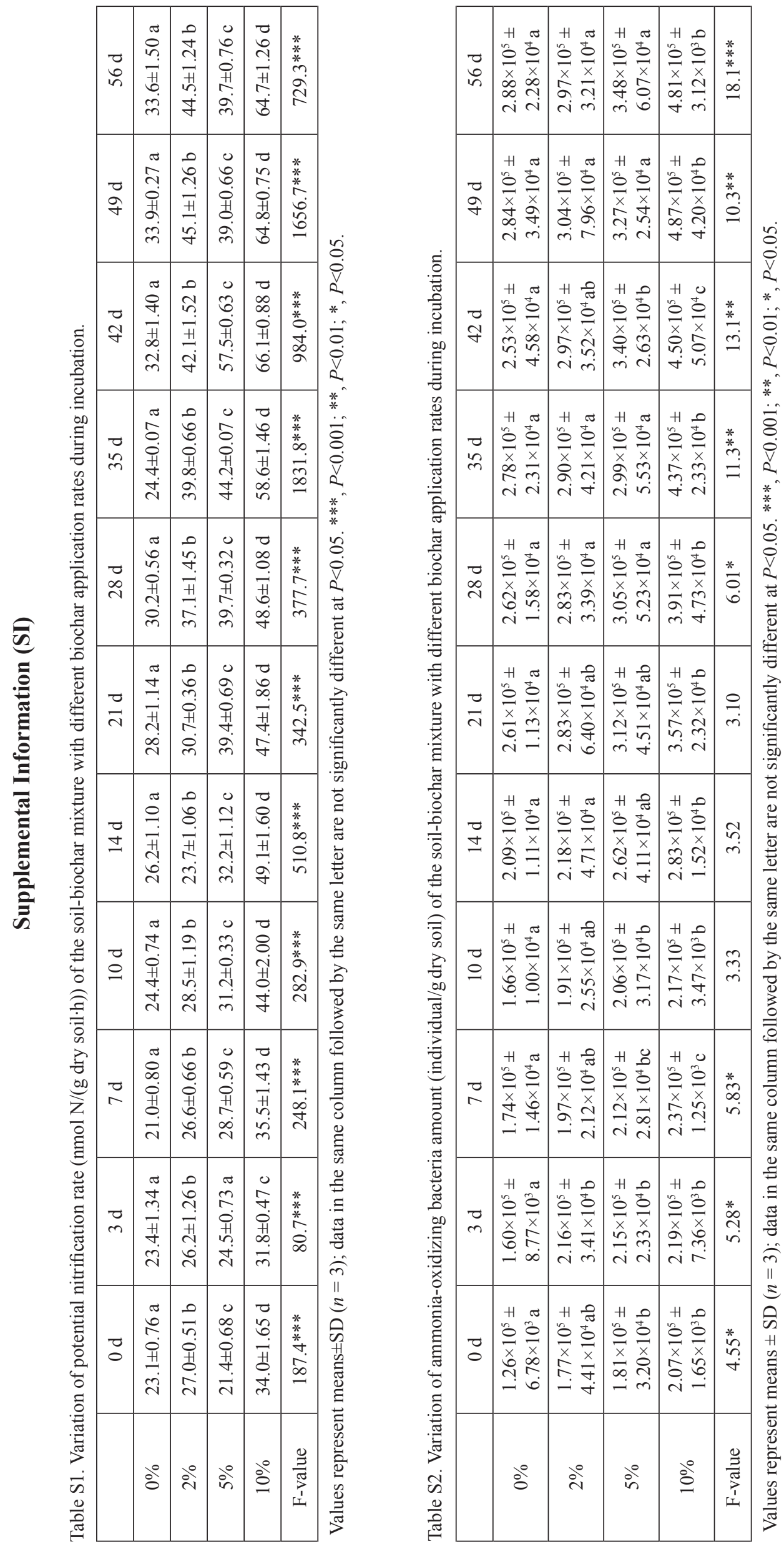


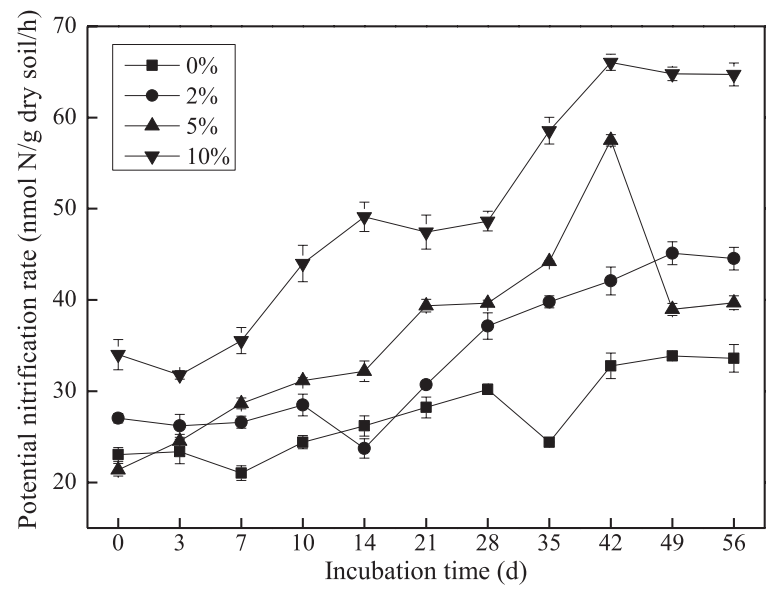

Fig. 1. Variation of potential nitrification rates of the soilbiochar mixture with different biochar application rates during incubation.

rates of $10 \%$ biochar application were 1.36-2.40 times more than that of control $(0 \%)$. On the other hand, the overall trends of the potential nitrification rate of all four treatments were elevated with incubation time elapsing. The potential nitrification rates of $0 \%, 2 \%, 5 \%$, and $10 \%$ biochar application rates were in the ranges of 21.0-33.9, 23.7-45.1, 21.4-57.5, and 31.8-66.1 $\mathrm{nmol} \mathrm{N} /(\mathrm{g}$ dry soil.h), respectively (Fig. 1).

With the same result as our study, other literatures also indicated that biochar enhanced nitrification in different types of acidic soils [12-14]. However, in a temperate alkaline soil ( $\mathrm{pH}$ 7.5), Prommer et al. showed that the gross nitrification rate in the hardwood-derived biochar treatment $(10.2 \mathrm{mg} \mathrm{N} /(\mathrm{g} \cdot$ day $))$ was fourfold higher than that of control (2.4 $\mathrm{mg} \mathrm{N} /(\mathrm{g} \cdot$ day $)$ ) [21]. The consistent stimulating effect of biochar on nitrification in either acidic or alkaline soils could be linked with ammonia-oxidizing bacteria (AOB) propagation, soil urease activity, $\mathrm{pH}$, and inorganic nitrogen contents of the biochar-amended soil ultimately. Therefore, determining the above-mentioned indices and their relationships with potential nitrification rate may be helpful for understanding the underlying mechanisms of biochar's positive effect on nitrification in the calcareous clay soil.

\section{Biochar's Effect on AOB Propagation and the Relationship with Potential Nitrification Rate}

As one of the main players in the nitrification process, $\mathrm{AOB}$ amount would be a direct indicator of potential nitrification rate in soil. The effect of biochar on AOB amount showed the same trend as potential nitrification rate, i.e., the $\mathrm{AOB}$ amount increased with biochar application rate increasing and incubation time elapsing as a whole. Moreover, relatively lower biochar application rates $(2 \%$ and $5 \%)$ may have no significant $(P<0.05)$ effect on AOB propagation in the calcareous clay soil.

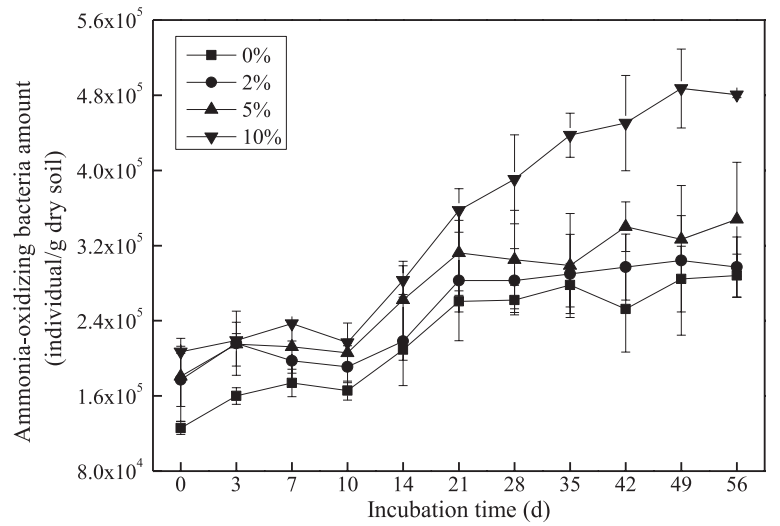

Fig. 2. Variation of ammonia-oxidizing bacteria amount of the soil-biochar mixture with different biochar application rates during incubation.

However, the $10 \%$ biochar application rate showed a significant $(P<0.05)$ effect on AOB amount increment at any incubation stage (Table S2, SI). At the $10 \%$ biochar application rate, the $\mathrm{AOB}$ amount increased from $2.07 \times 10^{5} \pm 1.65 \times 10^{3}$ to $4.81 \times 10^{5} \pm 3.12 \times 10^{3}$ individual $/ \mathrm{g}$ dry soil during the 56-day incubation, which were 1.64 and 1.67 times more than that of control, respectively (Fig. 2). Notably, statistical analysis showed that the effect of biochar on AOB amount became larger as incubation time was prolonged (Table S2, SI).

Understanding microbial colonization and adaptation processes is essential for clarifying the effect of biochar on AOB. Biochar's effect on AOB propagation may be in the adaptation process during the first 10-day incubation, and the positive effect was not very clear during the first three days. After that, biochar showed an obviously positive effect on AOB propagation (Fig. 2). Generally, the community size of AOB was enhanced by biochar application. This is consistent with the previous study indicating that dry montane forest soils subjected to biochar had higher numbers of bacterial amoA gene copy numbers than control soils [22]. The potential mechanism contributing to the biochar effect on microbial population may be attributed to the improved living environment for AOB caused by biochar. And the pore structure of biochar also became a good shelter for soil microbes to inhabit, protecting the soil beneficial microorganism and promoting microbial propagation [21].

Though $\mathrm{AOB}$ are not the sole player participating in the nitrification process (besides ammonia-oxidizing archaea (AOA)), many studies have shown that AOB dominated the nitrification process in different soils [2325]. Consistently, our study also indicated that the AOB amount was significantly and positively correlated with the potential nitrification rate $(r=0.899, P<0.01$; Table 1). Although Pereira et al. showed that even though net nitrification was increased by three kinds of biochar addition (Douglas fir wood pyrolyzed at $510^{\circ} \mathrm{C}$, pine chips pyrolyzed at $550^{\circ} \mathrm{C}$, and walnut shell gasified at $900^{\circ} \mathrm{C}$ ), the biochars showed no correlation with the abundance 


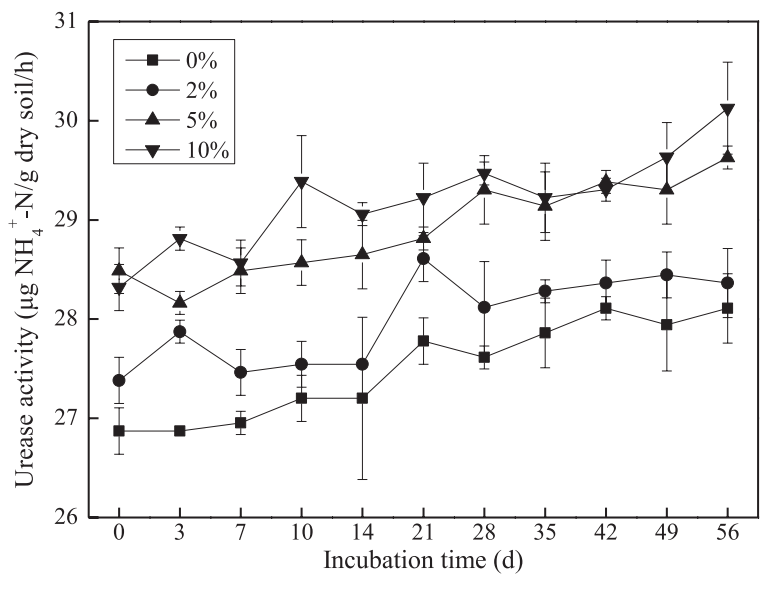

Fig. 3. Variation of urease activity of the soil-biochar mixture with different biochar application rates during incubation.

of ammonia-oxidizing prokaryotes in an organically managed lettuce mesocosm [26]. This phenomenon may be due to some other variables in soil related to nitrification besides the participators.

\section{Biochar's Effect on Soil Urease Activity and the Relationship with Potential Nitrification Rate}

Urease is a kind of hydrolytic enzyme that can promote organic-N matter degradation and can hydrolyze urea, releasing ammonia and carbon dioxide at the same time. Given that ammonia is the substrate of AOB, the urease activity of the soil-biochar mixture could indicate the nitrification potential indirectly. The urease activity of the soil-biochar mixture showed positive doseresponse to biochar application rate during incubation. Urease activity increased from 26.9, 27.4, 28.5, and $28.3 \mu \mathrm{g} \mathrm{NH}_{4}^{+}-\mathrm{N} /(\mathrm{g}$ dry soil.h) to $28.1,28.4,29.6$, and $30.1 \mu \mathrm{g} \mathrm{NH}_{4}^{+}-\mathrm{N} /(\mathrm{g}$ dry soil-h) during the 56 -day incubation period for the $0 \%, 2 \%, 5 \%$, and $10 \%$ biochar application rates, respectively (Fig. 3).

Nitrification rates have been shown to be strongly controlled by the ammonium supplied through soil $\mathrm{N}$ mineralization in a wide variety of ecosystem types, including woodland, grassland, and agricultural soils [27]. However, the degree of soil nitrogen mineralization was directly indicated by urease activity. Ammonium was generated through urea hydrolysis carried out by urease. Therefore, as the substrate of nitrification, $\mathrm{NH}_{4}^{+}{ }^{+} \mathrm{N}$ content increased with the increasing urease activity [28].

In our experiment, soil urease activity increased significantly during incubation, and showed positive dose-response to biochar application rate. Moreover, the correlation analysis showed that soil urease activity has a positive and significant $(r=0.793, P<0.01)$ relationship with potential nitrification rate (Table 1). In accordance with our study, some previous findings also testified the biochar's stimulating effect on urease activity. Jain et al. (2016) showed that lemongrass biochar addition enhanced the urease activity of soil [29]. In addition, the urease activity increased with the increase of maize biochar addition rate after a 90-day incubation [30]. Similarly, Bailey et al. indicated that adding biochar to soil could increase the activities of a series of enzymes related to $\mathrm{N}$ utilization [31]. What's more, biochar acts as a storehouse of carbon and other nutrients, which leads to more microbial growth. The enhancement of urease activity in biochar-amended soils was not for more nitrogen conversion, but for higher requirements of microbes, then promoting the biogeochemical cycling, such as nitrification [32].

\section{Biochar's Effect on $\mathrm{pH}$ and the Relationship with Potential Nitrification Rate}

Biochar has a liming effect, and nitrification occurring in soil would make the matrix more acidic, but how about the variation of the soil-biochar mixture $\mathrm{pH}$ during the incubation experiment? At the start of incubation, the $\mathrm{pH}$ of the soil-biochar mixture were $8.11 \pm 0.01,8.18 \pm 0.03$, $8.19 \pm 0.03$, and $8.25 \pm 0.03$ for the $0 \%, 2 \%, 5 \%$, and $10 \%$ biochar application rates, respectively. The $\mathrm{pH}$ of the soil-biochar mixture increased by $0.2-0.3$ units during incubation. However, $\mathrm{pH}$ showed no obvious doseresponse to biochar application rate. This phenomenon may be the coupled result of biochar liming effect and the abundant acidity generated by enhanced nitrification induced by biochar incorporation (Fig. 4).

Table 1. Pearson's correlation coefficients describing the relationships between potential nitrification rate and the related variables.

\begin{tabular}{|c|c|c|c|c|c|c|}
\hline & PNR & AOB amount & Urease activity & $\mathrm{pH}$ & $\mathrm{NH}_{4}^{+}-\mathrm{N}$ & $\mathrm{NO}_{3}-\mathrm{N}$ \\
\hline PNR & 1 & & & & & \\
\hline AOB amount & $0.899^{* *}$ & 1 & & & & \\
\hline Urease activity & $0.807^{* *}$ & $0.785^{* *}$ & 1 & & & \\
\hline $\mathrm{pH}$ & $0.713^{* *}$ & $0.852^{* *}$ & $0.612^{* *}$ & 1 & & \\
\hline $\mathrm{NH}_{4}{ }^{-}-\mathrm{N}$ & $-0.408^{* *}$ & $-0.466^{* *}$ & $-0.395^{* *}$ & $-0.473^{* *}$ & 1 & \\
\hline $\mathrm{NO}_{3}{ }^{-\mathrm{N}}$ & $0.714^{* *}$ & $0.726^{* *}$ & $0.691^{* *}$ & $0.735^{* *}$ & -0.292 & 1 \\
\hline
\end{tabular}

PNR: potential nitrification rate; AOB: ammonia-oxidizing bacteria; ${ }^{* *}$ : at 0.01 level (bilateral) was significantly associated; $n=44$ ). 


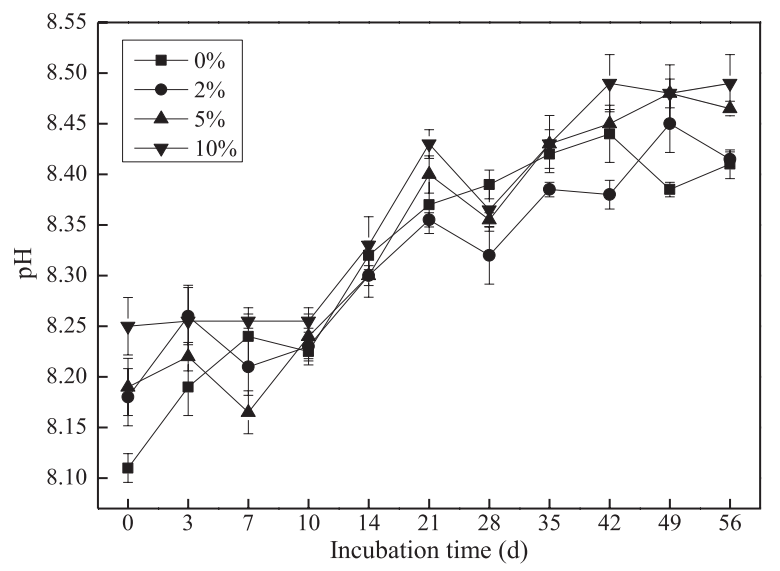

Fig. 4. Variation of $\mathrm{pH}$ of the soil-biochar mixture with different biochar application rates during incubation.

Generally, biochar is alkaline, and the addition of biochar could ameliorate acidic soil $\mathrm{pH}$ [33]. In the alkaline-arable soil ( $\mathrm{pH}$ 8.38) of the Great Plain of northern China, wheat straw-derived biochar $(\mathrm{pH}$ 10.4) addition has no significant effect on soil $\mathrm{pH}$ [34]. However, the soil used in our study was also alkaline ( $\mathrm{pH} 8.11 \pm 0.01$ ), and the $\mathrm{pH}$ slightly increased in response to wheat straw-derived biochar incorporation at the initial stage of incubation $(2 \%, 8.18 ; 5 \%, 8.19$; and $10 \%, 8.25$; Fig. 4). The increased $\mathrm{pH}$ created the beneficial circumstance for nitrifiers in the soil-biochar mixture, because nitrification is an alkalinity-consuming process [35]. Moreover, the biochar's liming effect provides a steady stream of alkalinity for nitrification during the incubation period. The positive and significant relationship was also verified between $\mathrm{pH}$ and potential nitrification rate in the soil-biochar mixture of our study $(r=0.713, P<0.01$; Table 1$)$. Correspondingly, a large number of studies showed that $\mathrm{pH}$ was the most important factor affecting the soil nitrification process and generally low $\mathrm{pH}$ was not conducive to nitrification [35-37].

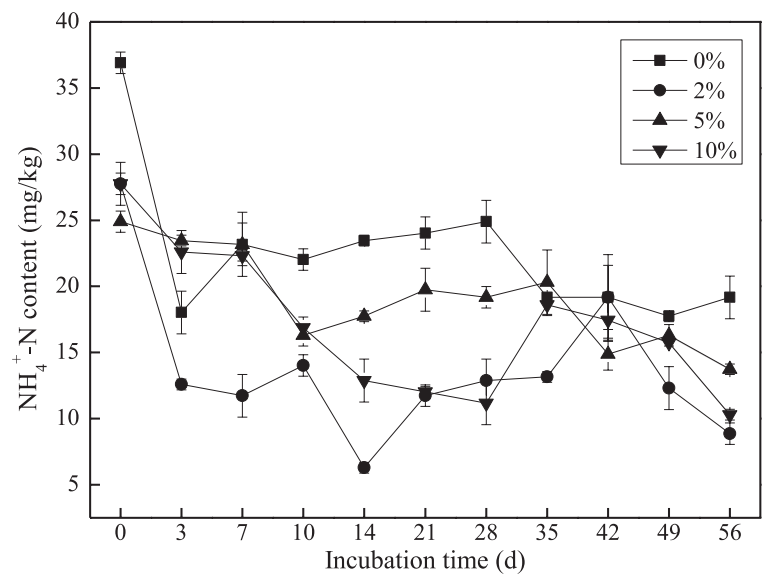

Fig. 5. Variation of $\mathrm{NH}_{4}^{+}-\mathrm{N}$ content of the soil-biochar mixture with different biochar application rates during incubation.

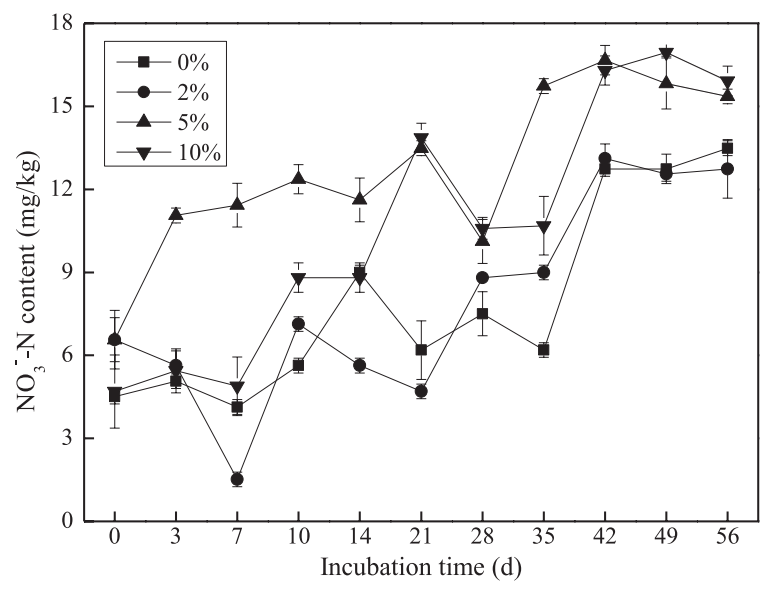

Fig. 6. Variation of $\mathrm{NO}_{3}^{-}-\mathrm{N}$ content of the soil-biochar mixture with different biochar application rates during incubation.

\section{Biochar's Effect on Inorganic Nitrogen Contents}

Ammonium and nitrate are the substrate and end product of the nitrification process, respectively. Then the variations of their contents in the soil-biochar mixture during incubation would be the main factors indicating nitrification intensity. $\mathrm{NH}_{4}^{+}$-N contents of the soil-biochar mixtures with $2 \%, 5 \%$, and $10 \%$ biochar additions were significantly $(P<0.05)$ lower than control at any incubation stage, indicating biochar's promotional effect on nitrification. The correlation analysis showed that the potential nitrification rate was significantly and negatively correlated with $\mathrm{NH}_{4}^{+}-\mathrm{N}$ content $(r=-0.408$, $P<0.01$; Table 1). What's more, during the 56-day incubation, $\mathrm{NH}_{4}^{+}-\mathrm{N}$ contents of the soil-biochar mixtures with $2 \%, 5 \%$, and $10 \%$ biochar additions declined by $68.1 \%, 45.0 \%$, and $62.9 \%$, respectively (Fig. 5).

Accordingly, $\mathrm{NO}_{3}^{-}-\mathrm{N}$ contents of the soil-biochar mixtures of $5 \%$ and $10 \%$ biochar application rates were significantly $(P<0.05)$ higher than control, also indicating biochar's promotional effect on nitrification. Correlation analysis showed that the potential nitrification rate was significantly and positively correlated with $\mathrm{NO}_{3}^{-}-\mathrm{N}$ content $(r=0.714, P<0.01$; Table 1$)$. Moreover, $\mathrm{NO}_{3}^{-}-\mathrm{N}$ contents of the soil-biochar mixtures with $5 \%$ and $10 \%$ biochar application rates increased by 1.34 and 2.38 times during the incubation, respectively (Fig. 6). These results were evident for verifying biochar's positive effect on nitrification.

\section{Conclusions}

The wheat straw-derived biochar enhanced nitrification in the calcareous clay soil of the Loess Plateau. Moreover, the potential nitrification rate increased with incubation time elapsing. Simultaneously, the ammoniaoxidizing bacteria amount, urease activity, $\mathrm{pH}$, and $\mathrm{NO}_{3}^{-}-\mathrm{N}$ content of the soil-biochar mixture all showed 
a positive and significant relationship with potential nitrification rate. The enhanced nitrification induced by biochar incorporation would aggravate $\mathrm{NO}_{3}^{-}$leaching to groundwater and impair ammonium bioavailability in the Loess Plateau agricultural system. Therefore, utilizing wheat straw-derived biochar in this region may have some environmental risks and should be investigated further.

\section{Acknowledgements}

This work was supported by the National Natural Science Foundation of China (Nos. 41503074 and 51408397), the Natural Science Foundation of Shanxi Province (No. 2015011081), the Qualified Personnel Foundation of Taiyuan University of Technology (QPFT; No. tyut-rc201266a), the Youth Foundation of Taiyuan University of Technology (No. 2013Z052), the Special Foundation of Taiyuan University of Technology (No. 2015MS031), and the Excellent Postgraduate Innovation Foundation of Shanxi Province (No. 20143049).

\section{References}

1. LIN D.X., FAN X.H., HU F., ZHAO H.T., LUO J.F. Ammonia volatilization and nitrogen utilization efficiency in response to urea application in rice fields of the Taihu Lake region, China. Pedosphere, 17 (5), 639, 2007.

2. TIAN Y.H., YIN B., YANG L.Z., YIN S.X., ZHU Z.L. Nitrogen runoff and leaching losses during rice-wheat rotations in Taihu Lake Region, China. Pedosphere, 17 (4), 445, 2007.

3. WANG Q.X., FAN X.H., WANG M.B. Precipitation trends during 1961-2010 in the Loess Plateau region of China. Acta Ecologica Sinica, 31 (19), 5512, 2011 [In Chinese].

4. KOLB S.E., FERMANICH K.J., DORNBUSH M.E. Effect of charcoal quantity on microbial biomass and activity in temperate soils. Soil Science Society of America Journal, 73 (4), 1173, 2009.

5. VERHEIJEN F, JEFFERY S., BASTOS A.C., VAN DER VELDE M., DIAFAS I. Biochar application to soils; Institute for Environment and Sustainability: Luxembourg, 2010.

6. LEHMANN J., DA SILVA JR J.P., STEINER C., NEHLS T., ZECH W., GLASER B. Nutrient availability and leaching in an archaeological Anthrosol and a Ferrolsol of the Central Amazon basin: fertilizer, manure and charcoal amendments. Plant and Soil, 249 (2), 343, 2003.

7. LAIRD D., FLEMING P., WANG B.Q., HORTON R., KARLEN D. Biochar impact on nutrient leaching from a Midwestern agricultural soil. Geoderma, 158 (3-4), 436, 2010.

8. SINGH B.P., HATTON B.J., SINGH B., COWIE A.L., KATHURIA A. Influence of biochars on nitrous oxide emission and nitrogen leaching from two contrasting soils. Journal of Environmental Quality, 39 (4), 1224, 2010.

9. KAMEYAMA K., MIYAMOTO T., SHIONO T., SHINOGI Y. Influence of sugarcane bagasse-derived biochar application on nitrate leaching in Calcaric dark red soil. Journal of Environmental Quality, 41 (4), 1131, 2011.
10. STEINER C., GLASER B., TEIXEIRA W.G., LEHMANN J., BLUM W.E.H., ZECH W. Nitrogen retention and plant uptake on a highly weathered central Amazonian Ferralso amended with compost and charcoal. Journal of Plant Nutrition and Soil Science, 171 (6), 893, 2008.

11. MAJOR J., RONDON M., MONLINA D., RIHA S.J., LEHMANN J. Nutrient leaching in a Colombian Savanna Oxisol amended with biochar. Journal of Environmental Quality, 41 (4), 1076, 2011.

12. DELUCA T.H., MACKENZIE M.D., GUNDALE M.J., HOLBEN W.E. Wildfire-produced charcoal directly influences nitrogen cycling in ponderosa pine forests. Soil Science Society of America Journal, 70 (2), 448, 2006.

13. VAN ZWIETEN L., KIMBER S., DOWNIE A., MORRIS S., PETTY S., RUST J., CHAN K.Y. A glasshouse study on the interaction of low mineral ash biochar with nitrogen in a sandy soil. Soil Research, 48 (7), 569, 2010.

14. NELISSEN V., RUTTING T., HUYGENS D., STAELENS J., RUYSSCHAERT G., BOECKX P. Maize biochars accelerate short-term soil nitrogen dynamics in a loamy sand soil. Soil Biology \& Biochemistry, 55, 20, 2012.

15. ZHANG A.F., CUI L.Q., PAN G.X., LI L.Q., HUSSAIN Q., ZHANG X.H., ZHENG J.W., CROWLEY D. Effect of biochar amendment on yield and methane and nitrous oxide emissions from a rice paddy from Tai Lake plain, China. Agriculture, Ecosystems \& Environment, 139 (4), 469, 2010.

16. ZHANG A.F., LIU Y.M., PAN G.X., HUSSAIN Q., LI L.Q., ZHENG J.W., ZHANG X.H. Effect of biochar amendment on maize yield and greenhouse gas emissions from a soil organic carbon poor calcareous loamy soil from Central China Plain. Plant and Soil, 351 (1), 263, 2012.

17. KUROLA J., SALKINOJA-SALONEN M., AARNIO T., HULTMAN J., ROMANTSCHUK M. Activity, diversity and population size of ammonia-oxidising bacteria in oil-contaminated landfarming soil. FEMS Microbiology Letters, 250 (1), 33, 2005.

18. LIN X.G. Principles and Methods of Soil Microbiology Research; Higher Education Press: Beijing, China, pp. 3738, 369-370, 2010 [In Chinese].

19. YAN C.S. Soil Fertility Research Methods; Agriculture Press: Beijing, China, pp. 141-147, 1988 [in Chinese].

20. ANDERSON J.M., INGRAM J.S.I. Tropical Soil Biology and Fertility: a Handbook of Methods; CAB International: Wallingford, UK, 1989.

21. PROMMER J., WANEK W., HOFHANSL F., TROJAN D., OFFRE P., URICH T., SCHLEPER C., SASSMANN S., KITZLER B., SOJA G., HOOD-NOWOTNY R.C. Biochar decelerates soil organic nitrogen cycling but stimulates soil nitrification in a temperate arable field trial. PloS ONE, 9 (1), e86388. 2014.

22. BALL P.N., MACKENZIE M.D., DELUCA T.H., HOLBEN MONTANA W.E. Wildfire and charcoal enhance nitrification and ammonium-oxidizing bacterial abundance in dry montane forest soils. Journal of Environmental Quality, 39 (4), 1243, 2010.

23. DI H.J., CAMERON K.C., SHEN J.P., WINEFIELD C.S., O'CALLAGHAN M., BOWATTE S., HE J.Z. Nitrification driven by bacteria and not archaea in nitrogen-rich grassland soils. Nature Geoscience, 2, 621, 2009.

24. BERNHARD A.E., LANDRY Z.C., BLEVINS A., DE LA TORRE J.R., GIBLIN A.E., STAHL D.A. Abundance of ammonia-oxidizing archaea and bacteria along an estuarine salinity gradient in relation to potential nitrification rates. Applied and Environmental Microbiology, 76 (4), 1285, 2010. 
25. WANG C.X., ZHU G.B., WANG W.D., YIN C.Q. Preliminary study on the distribution of ammonia oxidizers and their contribution to potential ammonia oxidation in the plant-bed/ditch system of a constructed wetland. Journal of Soils and Sediments, 13 (9), 1626, 2013.

26. PEREIRA E.I.P., SUDDICK E.C., MANSOUR I., MUKOME F.N.D., PARIKH S.J., SCOW K., SIX J. Biochar alters nitrogen transformations but has minimal effects on nitrous oxide emissions in an organically managed lettuce mesocosm. Biology and Fertility of Soils, 51 (5), 573, 2015.

27. BOOTH M.S., STARK J.M., RASTETTER E. Controls on nitrogen cycling in terrestrial ecosystems: A synthetic analysis of literature data. Ecological Monographs, 75 (2), 139, 2005.

28. DU Z.L., WANG Y.D., HUANG J., LU N., LIU X.R., LOU Y.L., ZHANG Q.Z. Consecutive biochar application alters soil enzyme activities in the winter wheat-growing season. Soil Science, 179 (2): 75, 2014.

29. JAIN S., MISHRA D., KHARE P., YADAV V., DESHMUKH Y., MEENA A. Impact of biochar amendment on enzymatic resilience properties of mine spoils. Science of the Total Environment, 544, 410, 2016.

30. WANG X.B., SONG D.L., LIANG G.Q., ZHANG Q., AI C., ZHOU W. Maize biochar addition rate influences soil enzyme activity and microbial community composition in a fluvo-aquic soil. Applied Soil Ecology, 96, 265, 2015.

31. BAILEY V.L., FANSLER S.J., SMITH J.L., BOLTON JR H. Reconciling apparent variability in effects of biochar amendment on soil enzyme activities by assay optimization. Soil Biology \& Biochemistry, 43 (2), 296, 2011.

32. HOPKINS D., DUNGAIT J.J. Soil microbiology and nutrient cycling. In: Soil Microbiology and Sustainable Crop Production; Dixon G.R., Tilston E.L., Eds., Springer: Netherlands, pp. 59, 2010.

33. SINGH B., SINGH B.P., COWIE A.L. Characterisation and evaluation of biochars for their application as a soil amendment. Soil Research, 48 (7), 516, 2010.

34. LIU X.Y., YE Y.X., LIU Y.M., ZHANG A.F., ZHANG X.H., LI L.Q., PAN G.X., KIBUE G.W., ZHENG J.F., ZHENG J.W. Sustainable biochar effects for low carbon crop production: A 5-crop season field experiment on a low fertility soil from Central China. Agricultural Systems, 129, 22, 2014.

35. HAYNES R.J. Nitrification. In: Mineral Nitrogen in the Plant-soil System; Haynes R.J., Ed., Academic Press: Orlando, Florida, pp. 127, 1986.

36. DANCER W.S., PETERSON L.A., CHESTERS G. Ammonification and nitrification of $\mathrm{N}$ as influenced by soil $\mathrm{pH}$ and previous $\mathrm{N}$ treatments. Soil Science Society of America Journal, 37 (1), 67, 1973.

37. ZEBARTH B.J., FORGE T.A., GOYER C., BRIN L.D. Effect of soil acidification on nitrification in soil. Canadian Journal of Soil Science, 95 (4), 359, 2015. 